\title{
Control of Leafy Spurge in Pastures Using Dicamba and 2,4-D
}

PAUL N.P. CHOW

\begin{abstract}
In the greenhouse, dicamba amine (dimethylamine of 3,6-dichloro-o-anisic acid) at 1.1 and $2.2 \mathrm{~kg} / \mathrm{ha}$ (a.i.) controlled young seedlings of leafy spurge (Euphorbia escula L.) and prevented shoot formation 66 days after herbicide application. The 2,4-D amine (dimethylamine of 2,4-dichlorophenoxyacetic acid) did not effectively control the growth of leafy spurge at 0.6 and $1.1 \mathrm{~kg} / \mathrm{ha}$, but gave good control at $2.2 \mathrm{~kg} / \mathrm{ha}$. In a separate test, dicamba at 2.2 $\mathrm{kg} / \mathrm{ha}$ controlled growth of shoots and roots of 100-day-old stands of leafy spurge more effectively than 2,4-D at the same rate. Dicamba killed mother stands and prevented the production of new shoots, whereas 2,4-D suppressed root growth of mother stands but induced more new shoot growth than found in untreated check plants. In a 5-year (1977-1981) field study (Brandon, Manitoba) of naturally established leafy spurge in a 'Carlton' smooth brome (Bromus inermis Leyss.) pasture, dicamba at 2.2 $\mathrm{kg} / \mathrm{ha}$, applied each year from 1977 to 1979 , controlled leafy spurge satisfactorily and resulted in increased smooth brome yield. The 2,4D at $2.2 \mathrm{~kg} / \mathrm{ha}$ controlled the weed satisfactorily in 1977 and 1979, but not in 1978 and 1981. The mixture of 2,4-D (2.2 $\mathrm{kg} / \mathrm{ha})$ and dicamba $(1.1 \mathrm{~kg} / \mathrm{ha})$ improved weed control and increased smooth brome yield. The smooth brome yield was inversely proportional to leafy spurge control. Under field conditions from 1978 to $1979,{ }^{14} \mathrm{C}$-dicamba in the plant translocated to the lower part of stems and accumulated in roots of established leafy spurge more readily than did ${ }^{14} \mathrm{C}-2,4-\mathrm{D}$, measured at 7,47 and 350 days after herbicide application. It was concluded tht dicamba applied each year gave better spurge control than 2,4-D and resulted in a large yield increase of smooth brome due to killing young seedlings and mother stands. This prevented the spread of root system and seed multiplication of leafy spurge on pasture.
\end{abstract}

Leafy spurge (Euphorbia escula L.) is an aggressive, persistent dicotyledonous perennial weed having the ability to tolerate a variety of habitats and to survive under unfavorable conditions. The vigorous spreading root system, which is an efficient storage organ for growth, often branches below the soil surface to produce erect clumps. It is propagated sexually from seeds and asexually from root buds. Seeds may remain viable in the soil for 8 to 13 years (Sellect et al. 1962). Seeds in the soil were unharmed by picloram (4-amino-3,5,6-trichloropicolinic acid) (Bowes and Thomas 1978). This weed is now widespread, threatening millions of hectares of pasture and rangeland in the prairie region of western Canada and the north central United States (Richardson 1968, Vore and Alley 1980). Studies in Canada indicated that leafy spurge was widely distributed in various soil zones of Saskatchewan and it was declared a noxious weed (Selleck et al. 1962). In the United States a 3-year (1975-1978) survey revealed that leafy spurge was found in 26 states since its introduction about 100 years ago (Dunn 1979). It

\footnotetext{
The author is research scientist in weed/herbicide physiology, Agriculture Canada Research Station, Brandon, Manitoba, R7A 5Z7, Canada.

The author wishes to acknowledge Velsicol Chemical Inc., for suppling Commercial and ${ }^{14} \mathrm{C}$-labelled dicamba for this study. The assistance of $\mathrm{A}$. McNutt and D. Czerkawski for conducting greenhouse and field experiments and of Ian S. Murchison for radioactivity measurement and sampling is appreciated.

Manuscript received January 19, 1983
}

was first discovered in North Dakota in 1909, increased to 40,000 hectares by 1973, and had infested an area of over 240,000 hectares by 1981 (Messersmith and Lym 1981). A similar situation was found in Wyoming (Vore and Alley 1980). Wyoming has developed a control program provided through the 1978 Leafy Spurge Control Act. An extensive leafy spurge awareness program has been conducted in Montana since 1980 (Barreto and Fay 1981).

In addition to its spreading characteristics, leafy spurge exhibits allelopathic properties (Steenhagen and Zimdahl 1979). Leaf and stem extracts inhibit germination of a number of plant species (Richardson 1968, Selleck et al. 1962). If eaten by cattle, it causes scours and weakness, often resulting in death (Muenscher 1940). Prostrate spurge (Euphorbia supina Raf.), a related species to leafy spurge, was found to be very inhibitory to several strains of nitrogen-fixing and nitrifying bacteria and to several associated seed plants (Rice 1969).

Mechanical control of leafy spurge with deep plough plowing is very expensive and not practical in pastures. Chemical control is feasible with herbicides that leave a residue in the soil for a reasonably long period. For controlling deep-rooted species such as leafy spurge, herbicides should have high mobility in the plant down to the roots. Dicamba (3,6-dichloro-o-anisic acid) is considered to be a very mobile herbicide (Ashton and Crafts 1973). It is readily translocated in phloem and xylem, and exuded to the soil by the roots of treated Canada thistle (Cirsium arvense L.) (Chang and Vanden Born 1968). Translocation of foliar-applied ${ }^{14} \mathrm{C}-2,4-\mathrm{D}(2,4-$ dichlorophenoxy acetic acid) into the shoots, roots, and root buds in greenhouse-grown seedlings was significantly increased both by shoot removal and by increasing the nitrogen supply (Hunter and McIntyre 1974). Low economic returns from pasture production tend to favor use of low-cost herbicides such as 2,4-D for suppressing leafy spurge growth. Trumpet-creeper [Campsis radicans (L.) Seem.], another deep-rooted woody perennial pasture weed, is controlled more effectively by dicamba than by 2,4-D (Thompson et al. 1973).

Despite the importance of leafy spurge, there is little research reported on its control This lack of information may be due to the lack of uniform stands on pasture under natural infestation for experimental evaluation and to the need for a relatively long period (several years) for evaluation of control methods. The objectives of the investigation reported here were (1) to measure the effect of dicamba and 2,4-D on growth of leafy spurge in the greenhouse; and (2) to compare the effectiveness of the 2 herbicides for the control of established leafy spurge on smooth brome pasture. The translocation and accumulation of ${ }^{14} \mathrm{C}$-dicamba and ${ }^{14} \mathrm{C}-2,4-\mathrm{D}$ in leafy spurge in microplots under natural pasture conditions were also compared.

\section{Materials and Methods}

\section{Greenhouse Investigation}

Under natural infestation conditions in the field, young seedlings grown from seeds and clumps from root buds in established mother stands are found simultaneously. It is necessary to measure 
Table 1. Effect of dicamba amine and 2,4-D amine on growth of leafy spurge seedlings, evaluated in two cuttings in the greenhouse.

\begin{tabular}{|c|c|c|c|c|c|}
\hline \multicolumn{2}{|c|}{ Treatment } & \multicolumn{2}{|c|}{1 st cutting 1,21 days after application } & \multicolumn{2}{|c|}{ 2nd cutting', 66 days after application } \\
\hline Herbicide & $\begin{array}{c}\text { Rate } \\
(\mathrm{kg} / \mathrm{ha})\end{array}$ & $\begin{array}{l}\text { Visual rating } \\
\left(0-9^{2}\right)\end{array}$ & $\begin{array}{l}\text { Fresh weight } \\
\text { (g/pot) }\end{array}$ & $\begin{array}{c}\text { Shoots } \\
\text { (no./pot) }\end{array}$ & $\begin{array}{c}\text { Fresh weight } \\
\text { (g/pot) }\end{array}$ \\
\hline $\begin{array}{l}\text { Untreated check } \\
\text { Dicamba } \\
\text { Dicamba } \\
\text { Dicamba }\end{array}$ & $\begin{array}{l}0 \\
0.6 \\
1.1 \\
2.2\end{array}$ & $\begin{array}{l}0 \mathrm{~d} \\
3.1 \mathrm{c} \\
3.6 \mathrm{~b} \\
8.9 \mathrm{a}\end{array}$ & $\begin{array}{l}2.4 \mathrm{a} \\
1.4 \mathrm{~b} \\
0.8 \mathrm{c} \\
0.4 \mathrm{~d}\end{array}$ & $\begin{array}{ll}6.3 \mathrm{a} \\
1.5 \mathrm{bc} \\
0 & \mathrm{c} \\
0 & \mathrm{c}\end{array}$ & $\begin{array}{ll}4.1 \mathrm{a} \\
0.5 \mathrm{bc} \\
0 & \mathrm{c} \\
0 & \mathrm{c}\end{array}$ \\
\hline $\begin{array}{l}2,4-D \\
2,4-D \\
2,4-D\end{array}$ & $\begin{array}{l}0.6 \\
1.1 \\
2.2\end{array}$ & $\begin{array}{l}2.9 \mathrm{c} \\
3.3 \mathrm{bc} \\
8.8 \mathrm{a}\end{array}$ & $\begin{array}{l}1.0 \mathrm{c} \\
0.8 \mathrm{~cd} \\
0.4 \mathrm{~d}\end{array}$ & $\begin{array}{l}4.3 \mathrm{~b} \\
3.5 \mathrm{~b} \\
0 \quad \mathrm{c}\end{array}$ & $\begin{array}{l}1.6 \mathrm{~b} \\
1.0 \mathrm{~b} \\
0 \mathrm{c}\end{array}$ \\
\hline
\end{tabular}

'Means within column followed by the same letter are not significantly different at the $5 \%$ level of probability according to Duncan's multiple range test.

${ }^{2}$ Visual rating, $0-9,9=$ complete kill.

the responses of both young seedlings and old stands to herbicides. Therefore, 2 types of greenhouse pot experiments were conducted.

\section{Effect of Herbicides on Young Seedlings}

Leafy spurge was seeded in pots containing $1,500 \mathrm{~g}$ Pipestone clay loam (a gleyed carbonated Rego Balck Chernozem) with 5.6\% organic matter and a $\mathrm{pH}$ of 7.5. After emergence, seedlings were thinned to 3 plants per pot. Water was added periodically to the surface of the soil as required for seedling growth. A photo-period of 16-hour was provided by flourescent lamps at $322 \mu \mathrm{E} \bullet \mathrm{m}^{-2} \cdot \mathrm{s}^{-1}$. Temperatures ranged from 16 to $23^{\circ} \mathrm{C}$ during the day and 12 to $18^{\circ} \mathrm{C}$ at night. The pots were arranged in a randomized complete block with 4 replicates. At 28 days of growth, seedlings were treated with 3 rates $(0.6,1.1$, and $2.2 \mathrm{~kg} / \mathrm{ha}$ a.i. $)$ of dicamba amine or 2,4-D amine. Visual rating $(0-9,9=100 \%$ kill) of weed control and fresh top weight (referred to as the first cutting) were recorded 21 days after herbicide application. After harvesting, the pots were watered and exposed to the lights under the same environmental conditions as described previously. Regrowth (including number of tillers and fresh weight) of shoots of leafy spurge (referred to as the second cutting) was measured 66 days after application (45 days after the first cutting).

\section{Effect of Herbicides on the Growth of Shoots and Roots in Established Stands.}

Three root stocks, $7.5 \mathrm{~cm}$ in length with 4 buds, were planted in pots $(22 \mathrm{~cm}$ diameter and $20 \mathrm{~cm}$ in depth) containing $4.5 \mathrm{~kg}$ Pipestone clay loam. Plants were grown in the greenhouse for 100 days, after which both dicamba amine or 2,4-D amine at $2.2 \mathrm{~kg} / \mathrm{ha}$ (a.i.) were applied. Untreated plants were used as a check. Seventyone days after treatment, roots were washed and the plants having mother stands and new shoots were separated out and measured or weighed. Five replicates in a randomized complete block were used and the pots were rearranged on the bench weekly.

\section{Field Experiments}

\section{Leafy Spurge Control and Smooth Brome Yield}

Heavy natural infestations of leafy spurge on smooth brome pasture [a Miniota sandy loam (Orthich Black Chernozem, level lacustrine and flacio-fluvial sand deposit) with organic matter 3.4\%] were chosen for the experiment. The population of leafy spurge was 35 plants $/$ per $\mathrm{m}^{2}$ and plant height averaged $40 \mathrm{~cm}$. For rigid selection of uniform stands, 3 replicates $(3 \times 9 \mathrm{~m})$ were arranged in a randomized complete block for the 5- year (1977 to 1981) evaluation period. Herbicides (rates listed in Table 3 ) were applied 1977 to 1979 in early July when leafy spurge was in the early bloom stage with vigorous vegetative growth. Herbicides were applied in 130 litres/ha of water at $310 \mathrm{kPa}$ of pressure. Visual ratings of weed control were made each year 6 to 8 weeks after herbicide application. Smooth brome yield was estimated from $3 \mathrm{~m}^{2}$ areas clipped at different sites in each plot in 1979 and 1981. Ground coverage by leafy spurge and smooth brome in each plot in 1981, 2 years after application of the herbicides, was also visually scored by 2 persons and averaged estimates were presented.

\section{Measurement of Labelled Herbicide Movement in Estab- lished Leafy Spurge}

In microplots $(0.5$ by $0.5 \mathrm{~m})$ in established stands 2 plants of similar size and height $(40 \mathrm{~cm}$ on average) were selected for each treatment in 3 replicates. In late July, plants with 7 to 8 yellow leaves within $7.5 \mathrm{~cm}$ of the top were dipped into diluted ${ }^{14} \mathrm{C}$ labelled herbicide solutions $\left[{ }^{14} \mathrm{C}\right.$-dicamba $(8.3 \mu \mathrm{Ci})$ alone or in mixture with $0.24 \mathrm{~kg} / \mathrm{ha} 2,4-\mathrm{D}$, and ${ }^{14} \mathrm{C}-2,4-\mathrm{D}(7.9 \mu \mathrm{Ci})$ alone or in mixture with $0.24 \mathrm{~kg} /$ ha dicamba] containing $0.25 \%$ Tween 20 (polyoxyethylene 20 sorbitan monolaurate) surfactant for $0.5 \mathrm{~min}$. This application procedure for radioactive solutions in the field is similar to that used by Jacobsohn and Andersen (1968). The treated and untreated plants were tagged with identification labels. On assigned dates $(7,47$, and 350 days after application), the plants were dug out, roots were washed, and tops and roots separated. Unabsorbed labelled herbicides on the tops of plants were washed with $95 \%$ ethanol for $1 \mathrm{~min}$. The plant tissues were dried at $50^{\circ} \mathrm{C}$ for 24 hours and ground to pass through a $420 \mu$ sieve. Three 100 $\mathrm{mg}$ samples were extracted with $95 \%$ ethanol. The extracts, $1.0 \mathrm{ml}$ in 3 replicates, were bleached with $0.5 \%$ benzoyl peroxide in the vial (Chow 1977). Radioactivity in the bleached extracts was counted in the scintillation toluene solution containing Triton $\mathrm{x}$-100 [octoxynol, $a,(p-1,1,3,3$-tetramethyl butylphenyl)- $w$-hydroxypoly(oxycthylene)] at 2:1 (v/v) by using a standard procedure.

Table 2. Effect of dicamba amine and 2,4-D amine on growth of 100-day-old stands of leafy spurge, measured 71 days after application in the greenhouse.

\begin{tabular}{|c|c|c|c|c|c|}
\hline \multicolumn{2}{|c|}{ Treatment } & \multirow[b]{2}{*}{$\begin{array}{c}\text { Alive mother stand } \\
\text { (no./pot) }\end{array}$} & \multirow[b]{2}{*}{$\begin{array}{l}\text { New shoots produced } 1 \\
\text { (no./pot) }\end{array}$} & \multicolumn{2}{|c|}{ Dry weight ${ }^{1}$} \\
\hline Herbicide & $\begin{array}{c}\text { Rate } \\
\text { (kg/ha) }\end{array}$ & & & $\begin{array}{l}\text { Shoots } \\
\text { (g/pot) }\end{array}$ & $\begin{array}{c}\text { Roots } \\
\text { (g/pot) }\end{array}$ \\
\hline $\begin{array}{l}\text { Untreated check } \\
\text { Dicamba } \\
2,4-D\end{array}$ & $\begin{array}{l}0 \\
2.2 \\
2.2\end{array}$ & $\begin{array}{l}1.0 \mathrm{a} \\
0.0 \mathrm{~b} \\
0.9 \mathrm{a}\end{array}$ & $\begin{array}{l}0.2 \mathrm{~b} \\
0.0 \mathrm{~b} \\
8.6 \mathrm{a}\end{array}$ & $\begin{array}{r}12.1 \mathrm{a} \\
3.4 \mathrm{~b} \\
11.4 \mathrm{a}\end{array}$ & $\begin{array}{r}10.1 \mathrm{a} \\
1.2 \mathrm{c} \\
3.7 \mathrm{~b}\end{array}$ \\
\hline
\end{tabular}

Means within column followed by the same letter are not significantly different at the $5 \%$ level of probability according to Duncan's multiple range test.

2Included mother stands and new shoot produced. 


\section{Results and Discussion}

Greenhouse Investigation

Effect of Herbicides on the Growth of young seedlings of leafy spurge

Dicamba at 3 rates $(0.6,1.1$ and $2.2 \mathrm{~kg} / \mathrm{ha})$ gave good control of young leafy spurge seedlings at a significant level compared to untreated check plants, as measured 21 days after herbicide application in the first cutting (Table 1). However, only the 1.1 and 2.2 $\mathrm{kg} / \mathrm{ha}$ rates killed the plants, as measured at 66 days in the second cutting. Only the $2.2 \mathrm{~kg} / \mathrm{ha}$ rate of $2,4-\mathrm{D}$ controlled leafy spurge seedlings and killed the plants. At these higher rates, the herbicides were probably toxic to buds and roots, which did not produce new shoots below the soil surface.

\section{Effect of Herbicides on the Growth of Shoots and Roots of} Established Stands

The application of dicamba at $2.2 \mathrm{~kg} / \mathrm{ha}$ killed all shoots including 100-day-old mother stands, and reduced shoot and root weight significantly in comparison with untreated plants (Table 2). The $2.2 \mathrm{~kg} / \mathrm{ha}$ rate of 2,4-D suppressed root growth but did not reduce mother stand numbers and shoot weights. These results on shoots were different from the previous experiment, probably because the leafy spurge plants were older, larger, and growing more vigorously, which may lead to resistance to the 2,4-D effect. The suppression of root growth by 2,4-D appeared linked to the stimulation of new shoots produced under the soil surface resulting in 8.6 new shoots per pot vs. 0.2 shoots for the untreated plants. Apical dominance associated with auxin in stem, tubers (Michener 1942), and roots (Thimann 1936) are common in the plant kingdom. If 2,4-D at this rate injures, but does not kill, the apex of the roots, it would be expected that the release of auxin effect on apexdominance would produce new shoots from the buds on the root system or stem under the soil surface.

\section{Field Experiment}

\section{Leafy Spurge Control and Smooth Brome Yield}

Visual ratings on weed control from 1977 to 1979 when the herbicides were applied showed that dicamba at $2.2 \mathrm{~kg} /$ ha consistently gave the best control (Table 3). Even in 1981, 2 years after the last application, dicamba still gave $84 \%$ control. The $2.2 \mathrm{~kg} /$ ha treatment of 2,4-D obtained 83 and $82 \%$ leafy spurge control in 1977 and 1979 , respectively, but only $62 \%$ control in 1978 . Two years after application, the control with 2,4-D was reduced to $16 \%$. Fresh weight production of leafy spurge also differed significantly, with herbicide treatment with 2,4-D treated plants out-weighing dicamba treated plants by 14 times in 1979 and 22 times in 1981 . The mixture of dicamba $(1.1 \mathrm{~kg} / \mathrm{ha})$ and $2,4-\mathrm{D}(2.2 \mathrm{~kg} / \mathrm{ha})$ improved weed control over $2,4-\mathrm{D}(2.2 \mathrm{~kg} / \mathrm{ha})$ applied alone. The highest yield of smooth brome in 1979 and 1981 resulted from successful control of leafy spurge with dicamba $(2.2 \mathrm{~kg} / \mathrm{ha})$. Smooth brome and leafy spurge production was much lower in 1981 than in 1979. Reduction in vegetative growth may be related to a number of factors, one of which may be the availability of soil moisture (Morrow 1979) because of continuously dry conditions from spring and summer in 1980 and low snowfall in the following winter. the growth competition between these 2 species appears to be strong. This was reflected in the inversely proportional ground coverage between the crop and the weed (Fig. 1). This also

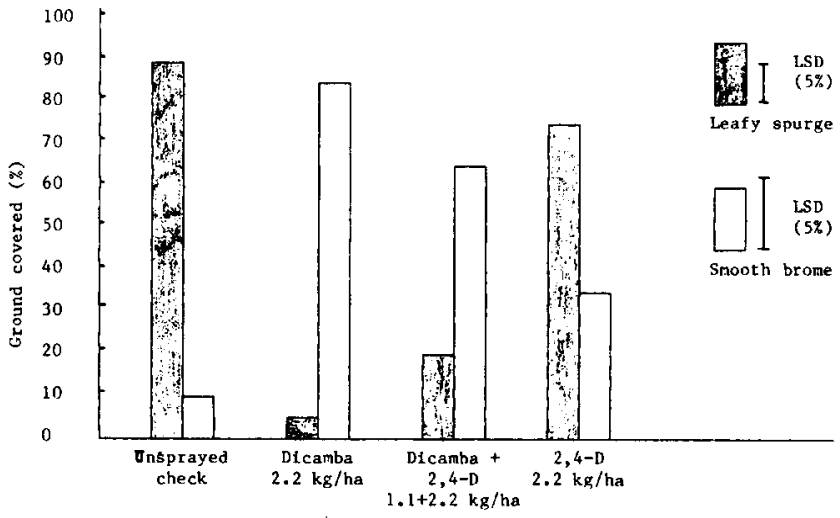

Fig. 1. The relationship of ground coverage in plots between leafy spurge and smooth brome, visually estimated in 1981.

indicated that maximum yield of smooth brome requires successful control of leafy spurge.

\section{Movement of ${ }^{14} C$-dicamba and ${ }^{14} C-2,4-D$ in Leafy Spurge}

The movement of ${ }^{14} \mathrm{C}$-dicamba from the top to the lower part of stems or to the roots was faster than was ${ }^{14} \mathrm{C}-2,4-\mathrm{D}$ movement (Table 4) as found in several other species (Chang and Vanden Born 1968, Thompson et al. 1973). Seven days after application and thereafter, ${ }^{14} \mathrm{C}$-dicamba alone or in a mixture with $2,4-\mathrm{D}$ moved faster and accumulated faster in roots than ${ }^{14} \mathrm{C}-2,4-\mathrm{D}$ alone or in mixture with dicamba probably because of free mobility of ${ }^{14} \mathrm{C}$-dicamba (Ashton and Crafts 1973). At 350 days after application, approximately half (47 to $48 \%$ ) of the ${ }^{14} \mathrm{C}$-dicamba had moved to the roots. In contrast, about 36 to $38 \%$ of ${ }^{14} \mathrm{C}-2,4-\mathrm{D}$ had moved to the roots and $62 \%$ remained in the stem. These findings may provide a partial explanation of differential activity of the herbicides against leafy spurge.

\section{Conclusion}

Results of this investigation indicated that leafy spurge in smooth brome pasture must effectively be controlled to obtain

Table 3. Leafy spurge control with dicamba and 2,4-D and smooth brome yield in the field.

\begin{tabular}{|c|c|c|c|c|c|c|c|c|c|c|c|}
\hline \multicolumn{4}{|c|}{ Treatment } & \multicolumn{6}{|c|}{ Leafy spurge control and date of evaluation! } & \multirow{2}{*}{\multicolumn{2}{|c|}{$\begin{array}{l}\begin{array}{c}\text { Smooth brome fresh } \\
\text { weight yield }\end{array} \\
\frac{(\mathrm{kg} / \mathrm{ha})}{1,2}\end{array}$}} \\
\hline \multirow[b]{2}{*}{ Herbicide } & \multicolumn{3}{|c|}{ Date and rate $(\mathrm{kg} / \mathrm{ha})$} & \multicolumn{4}{|c|}{ Visual rating $(\%)$} & \multicolumn{2}{|c|}{ Fresh weight (kg/ha) } & & \\
\hline & $\begin{array}{c}1977 \\
7-8\end{array}$ & $\begin{array}{r}1978 \\
7-6\end{array}$ & $\begin{array}{c}1979 \\
7-11\end{array}$ & $\begin{array}{r}1977 \\
8-16\end{array}$ & $9-5$ & $\begin{array}{r}1979 \\
8-7\end{array}$ & $\begin{array}{r}1981 \\
7-3\end{array}$ & $\begin{array}{c}1979 \\
7-10\end{array}$ & $\begin{array}{r}1981 \\
7-3\end{array}$ & $\begin{array}{c}1979 \\
7-10\end{array}$ & $\begin{array}{r}1981 \\
7-3\end{array}$ \\
\hline Unsprayed check & 0 & 0 & 0 & 0 d & $0 \mathrm{c}$ & $0 \mathrm{c}$ & $\mathbf{0 b}$ & $1033 \mathrm{a}$ & 867 a & $\begin{array}{l}1330 \mathrm{c} \\
(100)\end{array}$ & $\begin{array}{r}87 d \\
(100)\end{array}$ \\
\hline Dicamba & 2.2 & 2.2 & 2.2 & $81 \mathrm{c}$ & $84 \mathrm{a}$ & $82 \mathrm{~b}$ & $84 a$ & $34 \mathrm{c}$ & $32 \mathrm{c}$ & $\begin{array}{l}2591 \text { a } \\
(195)\end{array}$ & $\begin{array}{l}858 \mathrm{a} \\
(986)\end{array}$ \\
\hline $2,4-\mathrm{D}+$ & 2.2 & 2.2 & 2.2 & & & & & & & & \\
\hline dicamba & 1.1 & 1.1 & 1.1 & 88 a & $80 a$ & 85 a & $71 \mathbf{a}$ & $363 \mathrm{~b}$ & $158 \mathrm{~b}$ & $\begin{array}{l}2170 \mathrm{ab} \\
(163)\end{array}$ & $\begin{array}{l}617 \mathrm{~b} \\
(709)\end{array}$ \\
\hline 2,4-D & 2.2 & 2.2 & 2.2 & $83 \mathrm{~b}$ & $62 \mathrm{~b}$ & $82 \mathrm{~b}$ & $16 \mathrm{~b}$ & $479 \mathrm{~b}$ & $710 \mathrm{a}$ & $\begin{array}{l}1725 \text { bc } \\
(130)\end{array}$ & $\begin{array}{l}328 c \\
(377)\end{array}$ \\
\hline
\end{tabular}

IMeans within column followed by the same letter are not significantly different at the $5 \%$ level of probability according to Duncan's multiple range test.

${ }^{2}$ In each column values in parentheses represent yield in $\%$ of the unsprayed check. 
Table 4. Distribution of ${ }^{14} \mathrm{C}$-dicamba and ${ }^{14} \mathrm{C}-2,4-\mathrm{D}$ in the lower part of stem or roots of leafy spurge in the field.

\begin{tabular}{|c|c|c|c|c|c|}
\hline & \multirow[b]{2}{*}{ Treatment } & & \multicolumn{3}{|c|}{ Days after application } \\
\hline & & & \multirow{2}{*}{$\begin{array}{c}7 \\
\text { Lower part of stem } 1 \\
(\%)\end{array}$} & \multirow{2}{*}{$\begin{array}{c}47 \\
\text { Roots } \\
(\%)\end{array}$} & \multirow{2}{*}{$\begin{array}{c}350 \\
\begin{array}{c}\text { Roots } \\
(\%)\end{array}\end{array}$} \\
\hline Herbicide & $\begin{array}{l}\text { Labelled } \\
(\mu \mathrm{Ci})\end{array}$ & $\begin{array}{c}\text { Nonlabelled } \\
(\mathrm{kg} / \mathrm{ha})\end{array}$ & & & \\
\hline${ }^{14} \mathrm{C}$-dicamba & 8.3 & 0 & $8.1 \pm 0.2$ & $21.5 \pm 1.4$ & $46.8 \pm 0.1$ \\
\hline${ }^{14} \mathrm{C}$-dicamba & 8.3 & 0 & & & \\
\hline$+2,4-D$ & 0 & 0.24 & $6.3 \pm 0.2$ & $34.0 \pm 0.7$ & $48.2 \pm 0.4$ \\
\hline${ }^{14} \mathrm{C}-2,4-\mathrm{D}$ & 7.9 & 0 & $2.8 \pm 0.3$ & $10.1 \pm 0.1$ & $37.9 \pm 0.3$ \\
\hline${ }^{14} \mathrm{C}-2,4-\mathrm{D}$ & 7.9 & 0 & & & \\
\hline + dicamba & 0 & 0.24 & $2.0 \pm 0.6$ & $2.0 \pm 0.2$ & $35.5 \pm 0.3$ \\
\hline
\end{tabular}

IAfter cutting the treated tops, each stem was separated into lower and upper parts of equal length (a verage $15 \mathrm{~cm}$ ). Radioactivity in the roots was not measured on the 7 th day.

high yield of the crop. Dicamba at $2.2 \mathrm{~kg} / \mathrm{ha}$ applied in 3 consecutive years gave better leafy spurge control with 2,4-D at equal ratc and resulted in larger brome yield increases. Greenhouse experiments demonstrated that dicamba $(2.2 \mathrm{~kg} / \mathrm{ha})$ not only controlled young seedlings but also killed mother stands and inhibited new shoot production. This implied that in the field dicamba exerted herbicidal action to prevent the spread of leafy spurge, young seedlings and mother stands, and eventually reduced seed production.

\section{Literature Cited}

Ashton, F.M., and A.S. Crafts. 1973. Mode of action of herbicides. John Wiley \& Sons, Inc., New York.

Barreto, C.L., and P.K. Fay. 1981. Increasing awareness of leafy spurge (Euphorbia esula L.) spread. Abstr., p. 72., Weed Sci. Soc. Amer., 1981.

Bowes, G.G., and A.G. Thomas. 1978. Longevity of leafy spurge seeds in the soil following various control programs. J. Range Manage. 31:137-140.

Chang, F.Y., and W.H. Vanden Born. 1968. Translocation of dicamba in Canada thistle. Weed Sci. 16:176-181.

Chow, P.N.P. 1977. Bleaching of chlorophylls in alcohol extracts with benzoyl peroxide for liquid scintillation counting of ${ }^{14} \mathrm{C}$-labeled compounds.Anal. Biochem. 80:507-512.

Dunn, P.H. 1979. The distribution of leafy spurge (Euphorbia esula) and other weedy Euphorbia spp. in the United States. Weed Sci. 27:509-516.
Hunter, J.H., and G.I. McIntyre. 1974. Factors affecting translocations of 2,4-D in leafy spurge. Weed Sci. 22:167-171.

Jacobschn, R., and R.N. Andersen. 1968. Differential response of wild oat lines to diallate, triallate, and barban. Weed Sci. 16:491-494.

Messersmith, C.G., and R.G. Lym. 1981. Roller and wick application of picloram for leafy spurge control. Down to Earth 37:9-12.

Michener, D.H. 1942. Dormancy and apical dominance in potato tubers. Am. J. Botany 29:558-562.

Morrow, L.A. 1979. Studies on the reproductive biology of leafy spurge (Euphobia escula). Weed Sci. 27:106-109.

Muenscher, W.C. 1940. Poisonous plants of the United States. MacMillan Co., New York.

Rice, E.L. 1969. Inhibition of nitrogen-fixing and nitrifying bacteria by seed plants. VI. Inhibitors from Euphorbia supina. Physiol. Plant. 22:1175-1183.

Richardson, J.W. 1968. The genus Euphorbia of the high plains and prairie plains of Kansas, Nebraska, South and North Dakota. Univ. Kansas Sci. Bull. 48:45-112.

Selleck, G.W., R.T. Coupland, and C. Frankton. 1962. Leafy spurge in Saskatchewan. Ecol. Monogr. 32:1-29.

Steenhagen, D.A., and R.L. Zimdahl. 1979. Allelopathy of leafy spurge (Euphorbia esula). Weed Sci. 27:1-3.

Thimann, K.V. 1936. Auxins and the growth of roots. Am. J. Botany 23:561-569.

Thompson, L. Jr., C.H. Slack, R.D. Augenstein, and J.W. Herron. 1973. Action and fate of 2,4-D and dicamba in trumpetcreeper. Weed Sci. 21:429-432.

Vore, R., and H.P. Alley. 1980. Leafy spurge, menance to the West. Down to Earth 36:2-5.

CHANGE OF ADDRESS notices should be sent to the Managing Editor, 2760 West Fifth Ave., Denver, Colo. 80204, no later than the first day of the month of issue. Copies lost due to change of address cannot be replaced unless adequate notice is given. To assure uninterrupted service, provide your local postmaster with a Change of Address Order (POD Form 3575) indicating thereon to guarantee forwarding postage for second-class mail. 